\title{
PEMANFAATAN TEKNOLOGI INFORMASI DAN KOMUNIKASI TERHADAP USAHA JARING IKAN DI DESA ERIS, KECAMATAN ERIS, KABUPATEN MINAHASA
}

\author{
Imanuel K. Ch. Walingkas \\ Gene. H. M. Kapantow \\ Eyverson Ruauw
}

\begin{abstract}
The objective of this research is to study the use of information and communication technology on fish net enterprise at Eris Village Minahasa Regency. This research is conducted for three months from July, 2015 to September, 2015. This research uses census method with primary data taken directly by using questionnaire to interview 47 fisherman and secondary data regarding socioeconomic condition taken from government institution: Eris Village Office and Eris sub-district Office. The research result showed that only 55,32 percent of fisherman at Eris Village that use information and technology especially internet. The majority fisherman farmers are accessing internet via hand phone, smartphone, and tablet. The majority of fishermen using internet 80,77 percent have used to look for information related with fishing net business. The most dominant use of internet is for tool in buying product/need for fish net enterprise, followed by looking for information about the way/technique of fish net culture. The major constraint in using of internet at Eris Village is the still not good of internet connection (signal) and the low of farmer ability in accessing internet.
\end{abstract}

Keywords: the use of information and communication technology, fish net enterprise, Eris Village, Minahasa Regency

\begin{abstract}
ABSTRAK
Tujuan dari penelitian ini adalah untuk mempelajari penggunaan teknologi informasi dan komunikasi pada perusahaan jaring ikan di Desa Eris, Kabupaten Minahasa. Penelitian ini dilakukan selama tiga bulan dari Juli 2015 sampai September 2015. Penelitian ini menggunakan data primer dan pengambilan sampel menggunakan metode sensus. Wawancara langsung dilakukan pada petani jaring ikan dengan menggunakan kuesioner. Data sekunder diambil dari instansi pemerintah yaitu Kantor Desa Eris berupa sosial ekonomi masyarakat. Hasil penelitian menunjukkan bahwa hanya 55, 32 persen petani nelayan di Eris Village telah menggunakan informasi dan teknologi khususnya internet. Para petani nelayan mayoritas mengakses internet melalui handphone, smartphone, dan tablet. Mayoritas petani menggunakan internet 80,77 persen untuk mencari informasi yang berkaitan dengan usaha jaring ikan. Penggunaan yang paling dominan dari internet adalah sebagai alat untuk membeli produk dan kebutuhan usaha jaring ikan, diikuti dengan mencari informasi tentang cara atau teknik budiday jaring ikan. Kendala utama dalam penggunaan internet di Eris Village adalah masih tidak baik koneksi internet (sinyal) dan masih rendahnya kemampuan petani dalam mengakses internet.
\end{abstract}

Kata kunci: Teknologi Informasi, Komunikasi, Usaha Jaring Ikan, Desa Eris, Kabupaten Minahasa

\section{PENDAHULUAN}

\section{Latar Belakang}

Teknologi informasi dan komunikasi (TIK) saat ini sangat berkembang di masyarakat. Teknologi Informasi adalah sebuah teknologi yang dipergunakan untuk mengelola data, meliputi didalamnya: memproses, mendapatkan, menyusun, menyimpan, memanipulasi data dengan berbagai macam cara dan prosedur guna menghasilkan informasi yang berkualitas dan bernilai guna tinggi. Perkembangan TIK pun terus meningkat seiring 
dengan meningkatnya kebutuhan manusia. Menurut Martin (2002), teknologi informasi sendiri berarti, teknologi komputer yang digunakan untuk memproses dan menyimpan informasi serta teknologi komunikasi yang digunakan untuk mengirimkan informasi, seperti pengusaha bidang agribisnis juga dapat mendapatkan informasi-informasi berupa teknologi baru pada bidang pertanian yang pada akhirnya akan bermanfaat bagi kemajuan usahanya (Trimo, 2006). Teknologi Menurut Djoyohadikusumo (1994) berkaitan erat dengan sains dan perekayasaan. Dengan kata lain teknologi mengandung dua dimensi, yaitu sains dan perekayasaan yang saling berkaitan satu sama lainnya.

Perkembangan teknologi informasi dan komunikasi sekarang telah membawa pengaruh yang sangat besar terhadap kehidupan sosial budaya masyarakat (Anonim, 2003) sehingga kita dapat meniru atau menyerap kebudayaankebudayaan tersebut menjadi budaya cara hidup kita. Begitu juga menurut Natakusuma (2002), dengan berkembangnya penggunaan teknologi informasi dan komunikasi sebagai media pendidikan dilakukan dengan menggunakan media-media komunikasi seperti telepon, komputer internet, $e$-mail. Interaksi antara guru dan siswa tidak hanya dilakukan melalui tatap muka tapi melalui e-learning (Rosenberg, 2001).

Sekarang kita dapat memperoleh berbagai informasi secara cepat dan akurat melalui internet (Rachmawati, 2008) melakukan komunikasi dengan petani-petani kecil dengan segala keterbatasan yang mereka miliki, agar pesan yang disampaikan melalui komunikasi pertanian dapat diserap dan selanjutnya diterapkan dalam usahatani (Patihahuwan, 2010).

Bertambahnya pelaku usaha jaring ikan, dan supaya usahanya tetap bertahan bahkan berkembang, petani nelayan jaring ikan itu harus terus menggali informasi sekitar perkembangan jaring ikan dan meningkatkan mutu dari jaring ikan tersebut. Dalam menerapkan inovasi (ide-ide atau teknologi baru) baik teknologi produksi, teknologi sosial dan teknologi ekonomi pada petani guna meningkatkan sumberdaya pertanian seringkali mengalami hambatan-hambatan bahkan lebih dari itu inovasi tersebut tidak sampai pada tujuannya. oleh karena itu di perlukan materi serta media atau alat bantu yang dapat memberikan informasi yang sejelas-jelasnya mengenai keadaan sistim sosial dilingkungan petani, keadaan infrastruktur (penyuluhan, kredit, pendidikan dan keadaan alam (produktifitas tanah dan iklim (Rogers and Schoemaker, 1971; Husein, 1998).

Sejalan dengan pendapat Soekartawi (1988) mengemukakan bahwa walaupun telah banyak paket teknologi yang tersedia belum tentu petani dapat mengadopsinya secara langsung melainkan melalui suatu proses adopsi inovasi yang bertahap. Menurut Birowo (1986) adopsi inovasi justru terletak pada aspek-aspek sosial dan kelembagaan sedangkan aspek teknis dan ekonomis relatif lebih mudah di pecahkan. Hal ini di dukung oleh pendapat Lionberger (1980) yang menjelaskan bahwa keberhasilan pertanian melalui kelompok tani tidak hanya di tentukan oleh faktor ekonomi saja tetapi juga di tentukan oleh faktor sosial.

Sektor perikanan di Indonesia didukung oleh 2,5 juta kepala keluarga nelayan laut dan 800 ribu kepala keluarga petani ikan. Jumlah masyarakat yang bergerak disektor perikanan dengan luas areal yang harus dijelajahi tidak seimbang. Hal ini menyebabkan tingkat pemanfaatan sumberdaya perikanan masih sangat rendah. Karena baru mencapai 29,14\% dari potensi lestarinya. Saat ini produksi ikan di Indonesia $75 \%$ barasal dari penangkapan, sedangkan sisanya berasal dari kegiatan budidaya seperti disungai dan di danau yang berada di Kalimantan, Sumatera dan Sulawesi. Sedangkan jenis ikan yang dibudidayakan di tambak air payau dan air tawar banyak dilakukan di pulau jawa (Murtidjo, 1997 dalam Anonim, 2014).

Menurut Nurjana (2006) dalam Anonim (2014), perikanan air tawar dimulai sejak jaman penjajahan Belanda dengan penebaran benih ikan karper dan ikan mas di kolam halaman rumah di Jawa Barat, pada pertengahan abad 19. Praktek perikanan budidaya ini kemudian menyebar kepulau lain. Pada akhir 1970- an terjadi peningkatan produksi yang luar biasa dari budidaya ikan air tawar. Adanya pengenalan teknologi baru dalam perikanan memberikan kontribusi pada ketersediaan benih yang dihasilkan dan perkembangan pakan ikan. Spesies yang umum dibudidayakan adalah ikan karper/ikan mas (Cyprinus carpio), ikan gurami 
(Osphronemus goramy) dan ikan nila/mujair (Oreochromis niloticum).

Salah satu ikan air tawar adalah ikan nila/mujair. Ikan ini adalah ikan yang sangat mudah berkembang biak dan juga sangat cepat berkembangnya, sehingga ikan mujair cocok untuk dijadikan salah satu bentuk usaha untuk menambah pendapatan keluarga petani nelayan (Anonim 2014). Ikan mujair hidup secara berkelompok. Tempat hidup ideal untuk ikan mujair adalah diperairan tenang seperti bendungan, sungai dan danau air tawar. Meskipun ikan mujair dapat dipelihara di dalam akuarium, tapi tidak akan tumbuh secepat ikan mujair dibesarkan dikolam atau dialam terbuka ( Anonim, 2012 ). Dalam kondisi pasar yang cukup prospektif tidak banyak orang yang menekuni usaha perikanan, secara professional dan berorientasi komersial. Sehingga walaupun permintaan cukup tinggi penawaran ikan mujair masih dirasakan lamban. Akibatnya sekalipun untuk memenuhi permintaan lokal dan regional pasar ikan mujair masih terbuka lebar.

Pemanenan ikan mujair dapat dilakukan dengan dua cara yaitu panen total dan panen sebagian begitu juga penanganan pasca panen dapat dilakukan dengan cara penanganan ikan hidup dan penanganan ikan segar (Anonim, 2011). Kenyataan ini yang mendorong keinginan penulis untuk mengkaji lebih jauh tentang pemanfaatan teknologi informasi dan komunikasi terhadap usaha jaring ikan di Desa Eris.

Kemajuan pertanian yang telah dicapai dalam bidang teknologi informasi dan komunikasi di Desa Eris merupakan sesuatu yang patut di syukuri karena dengan kemajuan tersebut telah memudahkan petani nelayan dalam mengerjakan, menghasilkan bahkan memasarkan hasil usaha jaring ikan lebih baik. Hal ini dapat diketahui setelah penulis melakukan survei awal dimana sebagian petani nelayan sudah dan sementara mempergunakan teknologi informasi dan komunikasi khususnya penggunaan internet. Berapa persen petani nelayan yang menggunakan dan tidak menggunakan teknologi informasi perlu diketahui melalui penelitian ini.

Desa Eris merupakan ibukota Kecamatan yang terletak sekitar kurang lebih 700 meter dari permukaan laut yang merupakan salah satu wilayah pertanian khususnya tanaman tahunan dan tanaman setahun. Sehingga masyarakat pada waktu itu hidup dengan bercocok tanam. Pada tahun 1980-an masyarakat mulai mengenal budidaya ikan (Karamba), selanjutnya pada tahun 1990-an budidaya ikan mengalami perkembangan begitu pesat dengan menggunakan peralatan jaring (net) serta penanganan yang lebih baik, akibatnya masyarakat petani yang tadinya melaksanakan usaha bercocok tanam beralih ke usaha jaring ikan.

Sejalan dengan itu keadaan dilapangan menunjukkan bahwa akses untuk mendapatkan informasi seperti kegiatan-kegiatan penyuluhan masih sangat kurang, sehingga penggunaan teknologi informasi dan komunikasi di harapkan dapat menjadi solusi alternatif untuk memberikan informasi yang terbaru bagi petani/nelayan atau pengusaha ikan di Desa Eris Kecamatan Eris Kabupaten Minahasa.

\section{Rumusan Masalah}

Salah satu faktor yang menghambat peningkatan produksi dan pendapatan petani nelayan adalah kurangnya informasi dan komunikasi, salah satu cara untuk mendapatkan informasi adalah dengan memanfaatkan teknologi informasi dan komunikasi. Masalah dalam penelitian ini yaitu bagaimana penggunaan teknologi informasi dan komunikasi khususnya internet dalam pengembangan usaha jaring ikan yang berlangsung di Desa Eris Kabupaten Minahasa.

\section{Tujuan dan Manfaat}

Tujuan penelitian ini mendeskripsikan pemanfaatan teknologi informasi dan komunikasi khususnya internet dalam usaha jaring ikan di Desa Eris Kabupaten Minahasa. Manfaat penelitian ini sebagai sumber tambahan wawasan dalam memanfaatkan teknologi informasi dan komunikasi baik pada penulis maupun bagi pemerintah serta dapat berguna bagi perkembangan pertanian untuk petani lebih khusus bidang agribisnis.

\section{METODOLOGI PENELITIAN}

\section{Waktu dan Lokasi Penelitian}

Penelitian ini di laksanakan di Desa Eris

Kecamatan Eris Kabupaten Minahasa selama 3 
bulan yaitu dari bulan Juli 2015 sampai September 2015.

\section{Metode Pengambilan Data}

Metode yang digunakan dalam penelitian ini adalah metode survey. Data yang digunakan adalah data primer yang diambil secara langsung dengan menggunakan kuesioner. dan data sekunder yang didapat dari instansi pemerintah Kecamatan Eris berupa data sosial ekonomi masyarakat Sementara data sekunder adalah data yang diperoleh atau dikumpulkan peneliti dari berbagai sumber dalam hal ini Kantor Desa dan Kantor Kecamatan Eris.

Pengambilan data menggunakan metode Sensus, yaitu suatu metode dimana semua populasi akan diambil untuk pengamatan. Jumlah populasi 51 responden, akan tetapi yang terdata 47 responden. Data primer adalah data yang diperoleh atau dikumpulkan oleh peneliti secara langsung dari sumber datanya (responden). Untuk mendapatkan data primer, peneliti mengumpulkan dengan cara ketemu langsung dengan responden, dengan teknik antara lain observasi, wawancara, diskusi dengan berpedoman pada kuesioner (Anonim, 2012).

\section{Konsep Pengukuran}

Variabel-variabel yang diukur serta digunakan dalam penelitian ini adalah :

a. Karakteristik petani nelayan ikan meliputi : umur, tingkat pendidikan,pekerjaan utama, pekerjaan sampingan dan pengalaman bertani.

b. Karakteristik usaha jaring ikan meliputi ; luas lahan jaring ikan, banyaknya jaring ikan, status kepemilikan jaring ikan, status bibit ikan, status pakan ikan, jumlah tenaga kerja.

c. Pemanfaatan internet

d. Penggunaan internet oleh petani jaring ikan

e. Pemanfaatan internet dalam usaha jaring ikan

f. Sarana teknologi informasi komunikasi (TIK) selain internet yang digunakan

g. Kendala dalam pemanfaatan internet.

\section{Analisis Data}

Analisis data yang digunakan dalam penelitian ini secara deskriptif dan dijelaskan dalam bentuk Tabel.

\section{HASIL DAN PEMBAHASAN}

\section{Deskripsi Wilayah Penelitian}

\section{Letak dan Luas Wilayah}

Wilayah Kecamatan Eris secara umum memiliki luas wilayah $3976 \mathrm{Ha}$ terletak antara 1'11' sampai 1'12' lintang utara , 124'54' sampai 124'74 bujur timur, terdiri dari 8 Desa, terletak pada ketinggian 400-800 meter dari permukaan laut. Keadaan tanah datar berbukit dan pengunungan dengan tekstur tanah lempung berpasir dan merupakan ibukota Kecamatan serta mempunyai kawasan wisata pulau Likri sekaligus dengan usaha jaring ikan. Desa Eris merupakan salah satu Desa terletak di Kabupaten Minahasa tepatnya terletak di Kecamatan Eris , dengan luas wilayah $950 \mathrm{Ha}$, terbagi atas 7 dusun (jaga) dengan batas wilayah sebagai berikut :

- Sebelah utara berbatasan dengan Desa Tandengan 1

- Sebelah timur berbatasan dengan Desa Watulanei

- Sebelah selatan berbatasan dengan Desa Watumea

- Sebelah barat dengan danau Tondano

Secara adminstrasi Desa Eris yang merupakan ibukota kecamatan jaraknya dengan ibukota kabupaten kurang lebih $12 \mathrm{~km}$ sedangkan ibukota prospinsi mempunyai jarak kurang lebih $48 \mathrm{~km}$.

Teknologi informasi dan komunikasi yang memudahkan untuk mendapatkan informasi sebanyak-banyaknya, melalui teknologi komputer digunakan untuk memproses dan menyimpan informasi serta mengirimkan informasi dengan waktu singkat yang disebut internet, bagi desa Eris provider atau operator yang dapat digunakan atau dapat diakses bisa melalui telkomsel (simpati dan as), melalui speedy, indosat (mentari dan imtri), tri, dan smart fren. 


\section{Demografi Penduduk}

Jumlah penduduk Desa Eris Kecamatan Eris Kabupaten Minahasa yaitu 2002 jiwa dengan jumlah kepala keluarga $580 \mathrm{KK}$, akan tetapi yang hanya bisa dikaji sesuai sensus penduduk yaitu 1093 jiwa dengan jumlah 324 kepala keluarga (KK).

Kegiatan rutin yang dilakukan oleh warga Desa Eris Kecamatan Eris, meliputi kegiatan ibadah untuk umat kristiani seperti ibadah kolom, anak sekolah minggu, remaja, pemuda, kaum bapa dan ibu yang dilaksanakan setiap minggu, tetapi dengan hari yang berbedabeda. Selain itu ada kegiatan dasawisma, PKK desa dan arisan perangkat desa yang dilakukan selama seminggu sekali.

Tabel 1. Jumlah Penduduk Menurut Jenis Kelamin

\begin{tabular}{cccc}
\hline No & $\begin{array}{c}\text { Jenis } \\
\text { Kelamin }\end{array}$ & $\begin{array}{c}\text { Jumlah } \\
\text { (jiwa) }\end{array}$ & $\begin{array}{c}\text { Persentase } \\
(\boldsymbol{\%})\end{array}$ \\
\hline 1 & Laki-laki & 528 & 48,31 \\
2 & Perempuan & 565 & 51,69 \\
\hline & J u m l a h & 1093 & 100 \\
\hline
\end{tabular}

Sumber : Kantor Desa Eris, 2015

Dilihat dari Tabel 1 dapat disimpulakan jumlah penduduk Desa Eris Kecamatan Eris laki-laki 48,31\% lebih sedikit dari jumlah penduduk perempuan 51,69\%. Hal ini menunjukkan bahwa peran wanita mungkin akan lebih menonjol di bandingkan dengan laki-laki, sehingga bukan tidak mungkin akan mempengaruhi usaha yang mereka tekuni yaitu usaha tani nelayan ikan yang menopang dalam kehidupan mereka sehari-hari.

\section{Penduduk Berdasarkan Tingkat Pendidikan}

Salah satu faktor yang penting dalam dunia usaha adalah kecakapan, keahlian dan keterampilan individu tersebut mengupayakan usahanya (kualitas SDM). Peningkatan SDM erat hubungannya dengan pendidikan sebab dengan adanya pendidikan yang memadai, petani nelayan akan lebih mudah mengadopsi informasi-informasi dari berbagai sumber khususnya penggunaan internet.
Jumlah responden petani nelayan ikan di Desa Eris menurut tingkat pendidikan dapat dilihat pada Tabel 2.

Berdasarkan data pada Tabel 2, menunjukkan bahwa banyak masyarakat yang berpendidikan akhir tingkat lanjutan sekolah atas, 294 jiwa (26,90\%), sementara sekolah yaitu 296 jiwa $(27,08 \%)$. Hal ini menunjukkan hanya sebagian kecil masyarakat yang melanjutkan ke Perguruan Tinggi hanya $7,60 \%$ yang tamat kuliah. Sehingga dapat dikatakan kesadaran untuk melanjutkan studi di Desa Eris masih sangat kurang.

Tabel 2. Distribusi Penduduk Berdasarkan Tingkat Pendidikan di Desa Eris

\begin{tabular}{llcc}
\hline No & $\begin{array}{c}\text { Tingkat } \\
\text { Pendidikan }\end{array}$ & $\begin{array}{c}\text { Jumlah } \\
\text { (Orang) }\end{array}$ & $\begin{array}{c}\text { Persen- } \\
\text { tase (\%) }\end{array}$ \\
\hline 1 & Belum Sekolah & 54 & 4,94 \\
2 & Tamat SD & 178 & 16,28 \\
3 & Tamat SMP & 183 & 16,75 \\
4 & Tamat & 294 & 26,90 \\
& SMA/Sederajat & & \\
5 & Tamat kuliah & 83 & 7,60 \\
6 & Sementara & 296 & 27,08 \\
& Sekolah & & \\
7 & Tidak Sekolah & 5 & 0,45 \\
\hline & J u m l a h & 1093 & 100 \\
\hline
\end{tabular}

Sumber : Kantor Desa Eris, 2015

\section{Penduduk Berdasarkan Pekerjaan}

Distribusi Penduduk berdasarkan jenis mata pencaharian pokok penduduk Desa Eris dapat dilihat pada Tabel 3.

Data Tabel 3, menjelaskan bahwa pelajar dengan jumlah 296 orang atau 27,08\% yang paling banyak menjadi pekerjaan penduduk di desa Eris. Sementara tani bahkan nelayan masih lebih rendah lagi dari pekerjaan lain-lain yang mana pekerjaan mereka tidak menetap.

Hal ini yang menjadi masalah mengapa hal ini lebih tinggi, dibandingkan dengan pekerjaan-pekerjaan lainnya. Hal ini mungkin karena sebagian masyarakat sudah tidak memiliki tanah pertanian sebagai warisan, 
bahkan modal dalam usaha-usaha pertanian dan nelayan, sehingga ada yang bekerja sebagai sopir,wiraswasta PNS dan mengadalkan hasil pensiun usaha kecil menengah.

Tabel 3. Mata Pencaharian Pokok Penduduk Desa Eris

\begin{tabular}{clcc}
\hline No & $\begin{array}{c}\text { Jenis } \\
\text { Pekerjaan }\end{array}$ & Jumlah & $\begin{array}{c}\text { Persentase } \\
(\%)\end{array}$ \\
\hline 1 & Tani & 109 & 9,97 \\
2 & Nelayan & 51 & 4,67 \\
3 & Sopir & 11 & 1,01 \\
4 & PNS & 45 & 4,12 \\
5 & Honorer & 15 & 1,37 \\
6 & IRT & 115 & 10,52 \\
7 & Pelajar & 296 & 27,08 \\
8 & Pensiunan & 23 & 2,10 \\
9 & Pelaut & 11 & 1,01 \\
10 & Wiraswasta & 81 & 7,41 \\
11 & Belum & 63 & 5,76 \\
& Bekerja & & \\
12 & Pekerjaan & 2 & 0,18 \\
& Tidak Tetap & & \\
13 & Lain-lain & 271 & 24,80 \\
\hline & Jumlah & 1093 & 100 \\
\hline
\end{tabular}

Sumber : Kantor Desa Eris, 2015

\section{Karakteristik Responden}

Dalam penelitian ini karakteristik respondennya terdiri atas ; tingkat umur, tingkat pendidikan, pekerjaan responden dan pengalaman responden.

\section{Tingkat Umur Responden}

Faktor usia merupakan penentu dalam keberhasilan dan produktifitas suatu usaha taninelayan, secara umum umur para petani nelayan yang menjadi responden berada pada rentang umur 30 sampai 70 tahun. Dimana terdapat rentang umur yang sangat potensial karena merupakan umur yang tergolong produktif dengan tenaga yang dimiliki berada pada tingkat optimum sehingga kinerja dalam menjalankan usahatani relatif baik dan sangat mendukung. Tabel 4 menunjukkan jumlah dan persentase responden menurut umur.

Tabel 4 menunjukkan bahwa faktor umur responden tertinggi pada usia $41-50$ tahun $(36,17 \%)$, diikuti dengan umur 31 - 40 tahun dan umur 51 - 60 tahun dengan
$(21,28 \%)$ hal ini menunjukkan umur $31-40$ tahun merupakan usia yang paling produktif.

Tabel 4. Jumlah dan Persentase Responden Menurut Umur

\begin{tabular}{cccc}
\hline No & $\begin{array}{c}\text { Umur } \\
\text { (Tahun) }\end{array}$ & $\begin{array}{c}\text { Jumlah } \\
\text { responden } \\
\text { (Orang) }\end{array}$ & $\begin{array}{c}\text { Persentase } \\
(\%)\end{array}$ \\
\hline 1 & $21-30$ & 3 & 6,38 \\
2 & $31-40$ & 10 & 21,28 \\
3 & $41-50$ & 17 & 36,17 \\
4 & $51-60$ & 10 & 21,28 \\
5 & $>61$ & 7 & 14,89 \\
\hline & Jumlah & 47 & 100 \\
\hline
\end{tabular}

Sumber : diolah dari data primer, 2015

\section{Tingkat Pendidikan Responden}

Tingkat pendidikan responden, sangat menentukan dalam keberhasilan dari usaha tani nelayan. Semakin tinggi tingkat pendidikan petani nelayan maka semakin baik pula dalam mengambil keputusan, bahkan langkah-langkah untuk bagaimana mening-katkan produksi akan lebih cepat. Akan tetapi pemanfaatan teknologi informasi dan komunikasi terhadap usaha jaring ikan saat ini yang ada di Desa Eris menunjukkan jumlah petani nelayan yang menekuninya adalah tertinggi pada tingkat SMA yaitu 33 orang $(70,21 \%)$ diikuti dengan tingkat SD dan Perguruan tinggi. Untuk jelasnya dapat dilihat pada Tabel 5 .

\section{Tabel 5. Jumlah Responden Menurut Tingkat Pendidikan}

\begin{tabular}{cccc}
\hline No & $\begin{array}{c}\text { Tingkat } \\
\text { Pendidikan }\end{array}$ & $\begin{array}{c}\text { Jumlah } \\
\text { Petani } \\
\text { Nelayan } \\
\text { (Orang) }\end{array}$ & $\begin{array}{c}\text { Persentase } \\
(\%)\end{array}$ \\
\hline 1 & SD & 0 & 0 \\
2 & SMP & 9 & 19,15 \\
3 & SMA & 33 & 70,21 \\
4 & PT & 5 & 10,64 \\
\hline & J u m l a h & 47 & 100
\end{tabular}

Sumber : diolah dari data primer, 2015

\section{Pekerjaan Responden}

Pekerjaan responden terdiri dari pekerjaan utama dan pekerjaan sampingan seperti tertera pata Tabel 6 . 
Tabel 6. Jumlah Responden Berdasarkan Pekerjaan

\begin{tabular}{clcc}
\hline No & $\begin{array}{l}\text { Pekerjaan } \\
\text { Responden }\end{array}$ & $\begin{array}{c}\text { Jumlah } \\
\text { petani } \\
\text { nelayan } \\
\text { (Orang) }\end{array}$ & $\begin{array}{c}\text { Persentase } \\
(\%)\end{array}$ \\
\hline 1 & $\begin{array}{l}\text { Pekerjaan } \\
\text { Utama } \\
2\end{array}$ & 43 & 91,49 \\
& $\begin{array}{l}\text { Pekerjaan } \\
\text { Sampingan }\end{array}$ & 4 & 8,51 \\
\hline & Jumlah & 47 & 100 \\
\hline
\end{tabular}

Sumber : diolah dari data primer, 2015

Tabel 6 menunjukkan bahwa pekerjaan responden tidak begitu berpengaruh terhadap keberhasilan dari usaha jaring ikan, sebab sebagian besar responden mempunyai pekerjaan utama sebesar $91,49 \%$, hanya 8,51 yang memiliki pekerjaan sampingan.

Pengalaman Petani Nelayan Responden

Pengalaman petani pada biasanya semakin lama bertani akan semakin mempunyai pengalaman sehingga semakin tinggi tingkat keahliannya dalam usaha tani nya. Ini dapat dilihat pada Tabel 7 menunjukkan jumlah responden berdasarkan masa pengalaman petani nelayan.

Tabel 7. Jumlah dan Persentase Responden Menurut Lama Bertani

\begin{tabular}{cccc}
\hline No & $\begin{array}{c}\text { Lama } \\
\text { Bertani } \\
\text { ( Tahun } \\
\text { ) }\end{array}$ & $\begin{array}{c}\text { Jumlah } \\
\text { Responden } \\
\text { (Orang) }\end{array}$ & $\begin{array}{c}\text { Persentase } \\
(\%)\end{array}$ \\
\hline 1 & $5-10$ & 26 & 55,32 \\
2 & $11-20$ & 14 & 29,79 \\
3 & $21-30$ & 5 & 10,64 \\
4 & $>31$ & 2 & 4,25 \\
\hline & Jumlah & 47 & 100 \\
\hline
\end{tabular}

Sumber : diolah dari data primer, 2015

Hasil penelitian menunjukkan bahwa lama bertani 5 - 10 tahun jumlah respoden tertinggi yaitu 26 orang $(55,32 \%)$, kemudian diikuti oleh lama bertani $11-20$ tahun yaitu 14 orang $(29,79 \%)$, lama bertani $21-30$ tahun 5 orang $(10,64 \%)$ dan terakhir lama bertani $>31$ tahun yaitu 2 orang $(4,25 \%)$. Hal ini menunjukan bahwa lamanya bertani tidak menjadi suatu dasar bahwa seseorang itu dapat berhasil, ini lebih ditekankan pada hal ketekunan dan ada tidaknya modal dalam usaha tersebut. Sehingga usaha itu dapat berlangsung terus menerus dimana dapat menghidupkan petani nelayan hingga bertahun-tahun.

\section{Karakteristik Usahatani/Nelayan Luas Lahan Usaha Jaring Nelayan yang Dimiliki}

Luas lahan usaha jaring ikan setiap responden sangat ditentukan oleh tingkat kemampuan bagaimana petani jaring ikan ini dapat dan mampu mengelolanya. Dari Tabel 8 menunjukkan bahwa makin besar lahan jaring ikan yang dikelolah oleh petani, makin kurang petani nelayan yang menguasainya. Hal ini disebabkan karena tidak atau kurangnya modal penunjang dalam usaha jaring ikan. Disamping itu komunikasi dan informasi untuk lancarnya usaha ini belum terwujud. Menurut Trimo (2006) dalam usaha jaring ikan ini informasi-informasi berupa teknologi baru sangat diharapkan yang pada akhirnya akan bermanfaat bagi kemajuan usahanya.

Tabel 8. Luas Lahan Usaha Jaring Nelayan yang Dimiliki

\begin{tabular}{llc}
\hline No & $\begin{array}{c}\text { Luas Lahan } \\
\left(\boldsymbol{m}^{\mathbf{2}}\right)\end{array}$ & $\begin{array}{c}\text { Jumlah } \\
\text { Responden } \\
\text { (Orang) }\end{array}$ \\
\hline 1 & $<1000$ & 28 \\
2 & $1000-2000$ & 15 \\
3 & $2000-3000$ & 3 \\
4 & $>3000$ & 1 \\
\hline & Jumlah & 47 \\
\hline
\end{tabular}

Sumber : diolah dari data primer, 2015

\section{Banyaknya Jaring yang Digunakan oleh Responden}

Banyaknya jaring ikan yang dipergunakan ini sejalan dengan luas lahan usaha jaring ikan sebab makin banyak jaring ikan makin kurang petani yang memiliknya. Hal inipun disebabkan karena kurangnya modal dan kurangnya komunikasi dan informasi-informasi yang dapat meningkatkan usaha jaring ikan ini. jelasnya lihat pada Tabel 9. 
Tabel 9. Banyaknya Jaring yang Digunakan oleh Responden

\begin{tabular}{llc}
\hline No & $\begin{array}{c}\text { Banyaknya Jaring } \\
\text { (Jumlah) }\end{array}$ & $\begin{array}{c}\text { Jumlah } \\
\text { Responden } \\
\text { (Orang) }\end{array}$ \\
\hline 1 & $<30$ & 35 \\
2 & $30-60$ & 10 \\
3 & $60-90$ & 1 \\
4 & $>90$ & 1 \\
\hline & & Jumlah
\end{tabular}

Sumber : diolah dari data primer, 2015
Dampak dari kurangnya modal yang digunakan dalam usaha jaring ikan ini, menentukan pula pendapatan petani. Dengan kata lain pendapatan petani berkurang.

\section{Status Kepemilikan Responden}

Status kepemilikan responden meliputi kepemilikan jaring ikan, kepemilikan bibit ikan, kepemilikan pakan ikan dapat dilihat pada Tabel 10.

Tabel 10. Status Kepemilikan Jaring Ikan, Bibit Ikan, Pakan Ikan, Responden

\begin{tabular}{llccc}
\hline No & \multicolumn{1}{c}{$\begin{array}{c}\text { Status } \\
\text { Kepemilikan }\end{array}$} & $\begin{array}{c}\text { Jaring Ikan } \\
\text { Jumlah orang dan } \\
\text { persentase (\%) }\end{array}$ & $\begin{array}{c}\text { Bibit Ikan Jumlah } \\
\text { Orang dan } \\
\text { Persentase (\%) }\end{array}$ & $\begin{array}{c}\text { Pakan Ikan } \\
\text { Jumlah Orang dan } \\
\text { Persentase (\%) }\end{array}$ \\
\hline 1 & Milik sendiri & $47(100)$ & - & - \\
2 & Sewa & - & - & - \\
3 & Dibuat sendiri & - & $32(68,09)$ & - \\
4 & Barter/tukar & - & - & - \\
5 & Dibeli & $47(100)$ & $47(100)$ & $47(100)$ \\
\hline & \multicolumn{2}{c}{ Jumlah } & &
\end{tabular}

Sumber : diolah dari data primer, 2015

Tabel 10 menunjukkan bahwa, kepemilikan jaring ikan semuanya dimiliki sendiri oleh responden 47 orang $(100 \%)$ dan tidak ada yang disewakan, begitu pula dengan pembuatan pakan ikan semuanya dibeli yaitu 47 orang $(100 \%)$ dan tidak ada yang dibuat sendiri. Sementara untuk bibit ikan responden yang membuat sendiri 32 orang atau $(68,09 \%)$ dan yang membeli 15 orang atau $(31,91 \%)$. Dari hasil ini dapat dikatakan petani nelayan di Desa Eris belum sepenuhnya menguasai keterampilan, pengetahuan tentang bagaimana mengelola jaring ikan yang sebenarnya. Memang semua responden sudah memiliki jaring ikan dengan kata lain membuat sendiri tetapi untuk membuat sendiri pakan ikan tidak ada semuanya dibeli. Hal ini menunjukan apakah petani nelayan tidak dapat membuat pakan sendiri. Begitu pula dengan bibit ikan masih ada $31,91 \%$ responden yang membeli bibit ikan belum seluruhnya membuat sendiri. Hal ini apabila bibit ikan semuanya dibuat sendiri oleh petani, ini tentunya akan meningkatkan nilai tambah dari usaha jaring ikan.

\section{Jumlah Tenaga Kerja dari Usaha Jaring Ikan}

Jumlah tenaga kerja dalam usaha jaring ikan keseluruhan baik tenaga kerja harian maupun keluarga dapat dilihat pada Tabel 11. Hasil penelitian menunjukan bahwa tenaga kerja yang pakai dalam usaha jaring ikan di Desa Eris umumnya mempergunakan tenaga kerja 2 orang persatu usaha jaring. Tertinggi 22 orang $(46,81)$ kemudian diikuti oleh tenaga kerja 1 orang dengan 18 orang atau $38,30 \%$, dan terakhir 3 dan 4 orang dengan persentase yang lebih sedikit.

Hal ini menunjukkan bahwa usaha jaring ikan ini masih merupakan usaha kecil yang hanya mampu dikelolah dan mampu menghidupkan keluarga petani saja, walaupun dilihat dari lapangan pekerjaan sudah dapat memberikan manfaat bagi masyarakat melihat tenaga kerja yang dapat di tampung adalah 8 orang tenaga kerja. 
Tabel 11. Jumlah Tenaga Kerja yang dipakai oleh Responden

\begin{tabular}{ccccc}
\hline No & $\begin{array}{c}\text { Tenaga kerja } \\
\text { yang dipakai } \\
\text { (orang) }\end{array}$ & $\begin{array}{c}\text { Jumlah Responden } \\
\text { (orang) }\end{array}$ & Persentase (\%) & $\begin{array}{c}\text { Jumlah tenaga kerja } \\
\text { keseluruhan }\end{array}$ \\
\hline 1 & 1 orang & 18 & 38,30 & 18 \\
2 & 2 orang & 22 & 46,81 & 44 \\
3 & 3 orang & 4 & 8,51 & 12 \\
4 & 4 orang & 3 & 6,38 & 12 \\
\hline & Jumlah & 47 & 100 & 86 \\
\hline
\end{tabular}

Sumber : diolah dari data primer, 2015

Tabel 12. Pemanfaatan Internet oleh Responden

\begin{tabular}{clcc}
\hline No & $\begin{array}{c}\text { Manfaat internet untuk } \\
\text { pengembangan usaha tani }\end{array}$ & $\begin{array}{c}\text { Jumlah Responden } \\
\text { (Orang) }\end{array}$ & Persen-tase (\%) \\
\hline 1 & Tidak bermanfaat sama sekali & 5 & 10,64 \\
2 & Sedikit bermanfaat & 2 & 4,25 \\
3 & Cukup bermanfaat & 14 & 29,79 \\
4 & Sangat Bermanfaat & 26 & 55,32 \\
\hline & Jumlah & 47 & 100 \\
\hline
\end{tabular}

Sumber : diolah dari data primer, 2015

\section{Pemanfaatan Internet}

Pemanfaatan internet oleh responden terhadap usaha jaring ikan merupakan faktor yang sangat penting untuk keberhasilan. ini dapat dilihat pada Tabel 12 .

Tabel 13. Pemanfaatan Internet oleh Responden

\begin{tabular}{cccc}
\hline No & $\begin{array}{c}\text { Penggunaan } \\
\text { Internet oleh } \\
\text { responden }\end{array}$ & $\begin{array}{c}\text { Jumlah } \\
\text { Responden } \\
\text { (Orang) }\end{array}$ & $\begin{array}{c}\text { Persen- } \\
\text { tase } \\
(\%)\end{array}$
\end{tabular}

$\begin{array}{llcc}1 & \begin{array}{l}\text { Menggunakan/ } \\ \text { mengakses }\end{array} & 26 & 55,32 \\ 2 & \begin{array}{l}\text { Tidak Meng- } \\ \text { gunakan/menga } \\ \text { kses }\end{array} & 21 & 44,68\end{array}$

\begin{tabular}{ccc}
\hline Jumlah & 47 & 100 \\
\hline
\end{tabular}

Sumber : diolah dari data primer, 2015

Tabel 13. Menunjukkan bahwa tingkat penggunaan internet oleh responden $55,32 \%$ menggunakan internet, sedangkan yang tidak menggunakan 44,68\%. Menurut Martin (2002), teknologi informasi seperti teknologi komputer yang digunakan untuk proses dan menyimpan informasi serta teknologi komunikasi yang digunakan untuk mengirimkan informasi dengan waktu yang singkat, belum sepenuhnya diterima bahkan hanya sebagian masyarakat tani yang mempergunakannnya di Desa Eris. Mereka belum begitu mengetahui bahwa, perkembangan teknologi informasi dan komunikasi dapat membantu dan memberikan dampak bagi kemajuan usaha sektor pertanian dalam hal ini usaha jaring ikan. Pengenalan bidang pertanian melalui medi-media informasi seperti internet misalnya diharapkan dapat menarik minat masyarakat tani khususnya petani nelayan agar meningkatkan citra pertanian.

\section{Responden yang Belum Mengakses atau Belum Menggunakan Internet}

Adanya petani Responden yang belum mengakses internet sebanyak 21 orang mempunyai alasan-alasan tersendiri ini dapat dilihat pada Tabel 14. Selanjutnya

ketertarikan responden untuk mengakses internet atau ingin menggunakan internet dari 21 orang responden ada sebanyak 19 orang 
responden dan yang tidak menjawab 2 orang responden. Hal menunjukkan bahwa dari niat responden untuk mengetahui atau mempergunkan internet sangat besar namun karena keterbatasan perangkat untuk mengakses, sehingga hal ini tidak dapat dilakukan.

Tabel. 14 Alasan adanya responden yang belum pmengakses internet

\begin{tabular}{clc}
\hline No & \multicolumn{1}{c}{$\begin{array}{c}\text { Alasan belum } \\
\text { mengakses Internet }\end{array}$} & $\begin{array}{c}\text { Responden } \\
\text { (Orang) }\end{array}$ \\
\hline 1 & $\begin{array}{l}\text { Belum pernah tau apa } \\
\text { itu internet } \\
\text { Tidak punya } \\
\text { komputer/perangkat } \\
\text { lain untuk mengakses } \\
\text { internet } \\
\text { Tidak ada koneksi ke } \\
\text { internet } \\
\text { Biaya akses internet } \\
\text { mahal } \\
\text { Lain-lain }\end{array}$ & 11 \\
\hline & Jumlah & - \\
\hline Sumber diolah & 21 \\
\hline
\end{tabular}

Sumber : diolah dari data primer, 2015

\section{Responden yang Sudah Mengakses atau Menggunakan Internet}

Jenis informasi dan komunikasi yang digunakan oleh responden lewat berbagai media komunikasi dapat dilihat pada Tabel 15.

Tabel 15. Jenis Informasi dan Komunikasi yang Diakses Petani Nelayan Responden Lewat Berbagai Media Komunikasi

\begin{tabular}{clcc}
\hline No & $\begin{array}{l}\text { Jenis pesan } \\
\text { informasi }\end{array}$ & $\begin{array}{c}\text { Jumlah } \\
\text { responden } \\
\text { mengakses } \\
\text { (orang) }\end{array}$ & $\begin{array}{c}\text { Persen- } \\
\text { tase } \\
(\%)\end{array}$ \\
\hline 1 & $\begin{array}{l}\text { Komputer } \\
\text { Rumah }\end{array}$ & 2 & 7,69 \\
2 & $\begin{array}{l}\text { Komputer } \\
\text { Kelompok } \\
\text { Tani }\end{array}$ & - & - \\
3 & $\begin{array}{l}\text { Komputer } \\
\text { kantor }\end{array}$ & - & - \\
4 & Warnet & 2 & 7,69 \\
5 & $\begin{array}{l}\text { Telepon } \\
\text { Genggam/Sma } \\
\text { rtphone/ }\end{array}$ & 22 & 84,62 \\
& Tablet & & \\
\hline & \multicolumn{1}{c}{ Jumlah } & 26 & 100 \\
\hline
\end{tabular}

Sumber : diolah dari data primer, 2015
Jenis informasi dan komunikasi yang digunakan oleh petani nelayan di desa Eris umumnya mempergunakan telpon genggam/smarthone/tablet dengan $84,62 \%$ diikuti oleh komputer rumah dan warnet dengan 7,69\%. Hal ini menunjukkan bahwa petani nelayan di desa Eris cendrung menggunakan alat internet yang lebih praktis.

Selanjutnya biaya rata-rata per bulan yang dikeluarkan oleh responden, dalam rangka mengakses internet, untuk keperluan apa mengakses internet, serta apakah menggunakan internet untuk mencari informasi sehubungan dengan usaha jaring ikan dan selanjutnya jika ya untuk apa responden menggunakan internet, dapat dilihat pada Tabel 16.

Tabel 16. Biaya Rata-Rata Per Bulan yang Dikeluarkan oleh Responden

\begin{tabular}{cccc}
\hline No & $\begin{array}{c}\text { Biaya } \\
\text { Pengeluaran } \\
(\mathbf{R p})\end{array}$ & $\begin{array}{c}\text { Jumlah } \\
\text { Responden } \\
\text { (orang) }\end{array}$ & $\begin{array}{c}\text { Persen- } \\
\text { tase }(\boldsymbol{\%})\end{array}$ \\
\hline 1 & $<50.000$ & 5 & 19,23 \\
2 & $50.000-$ & 16 & 61,54 \\
& 100.000 & & \\
3 & $100.000-$ & 4 & 15,38 \\
& 200.000 & & \\
4 & $>200.000$ & 1 & 3,85 \\
\hline & Jumlah & 26 & 100 \\
\hline
\end{tabular}

Sumber : diolah dari data primer, 2015

Sejalan dengan alat yang digunakan oleh petani nelayan di desa Eris yaitu telepon genggam, maka rata-rata biaya yang dikeluarkan oleh responden terbesar adalah 50.000-100.000 dengan prersentase $61,54 \%$, diikuti berturut-turut oleh $<50.000$, dengan persentase $19,23 \%$, 100.000-200.000 dengan persentase $15,38 \%$ dan yang terendah dengan biaya $>200.000$ pada persentase $3,85 \%$.

Pada Tabel 18 menunjukkan bahwa ada 21 orang responden atau $80,77 \%$ mempergunakan internet untuk usaha jaring ikan, tujuannya mencari informasi, cara/teknik budidaya ikan, mencari informasi harga,mencari informasi pengembangan kelompok, membeli produk dan menjual produk. dan kepemilikan jaring ikan merupakan kebutuhan utama dalam usaha jaring ikan sehingga ini merupakan suatu alasan, responden memilih lebih banyak. 


\section{Tabel 17. Tujuan Mengakses Internet oleh Responden}

\begin{tabular}{clcc}
\hline No & \multicolumn{1}{c}{ Tujuan mengakses internet } & Responden (orang) & Persen-tase (\%) \\
\hline 1 & $\begin{array}{l}\text { Komunikasi (email, facebook, } \\
\text { tweeter, chatting) }\end{array}$ & 13 & 50,00 \\
2 & Membaca berita & 1 & 3,85 \\
3 & Jual/beli & 4 & 15,38 \\
4 & Mencari informasi & 8 & 30,77 \\
\hline & Jumlah & 26 & 100
\end{tabular}

Sumber : diolah dari data primer, 2015

Tabel 18. Responden Mengakses Internet dalam Usaha Jaring Ikan

\begin{tabular}{cccc}
\hline No & $\begin{array}{c}\text { Apakah mengunakan internet dalam } \\
\text { rangka usaha jaring ikan }\end{array}$ & Responden (Orang) & Persentase (\%) \\
\hline 1 & Ya & 21 & 80,77 \\
2 & Tidak & 5 & 19,23 \\
\hline & Jumlah & 26 & 26 \\
\hline
\end{tabular}

Sumber : diolah dari data primer, 2015

Tabel 19. Kegunaan yang diperoleh Responden melalui Internet dalam Rangka Usaha Jaring Ikan

\begin{tabular}{clcc}
\hline No & \multicolumn{1}{c}{$\begin{array}{c}\text { Kegunaan } \\
\text { mengakses } \\
\text { Internet }\end{array}$} & $\begin{array}{c}\text { Respo } \\
\text { n-den } \\
\text { (Oran } \\
\text { g) }\end{array}$ & $\begin{array}{c}\text { Persen- } \\
\text { tase (\%) }\end{array}$ \\
\hline 1 & $\begin{array}{l}\text { Mencari informasi } \\
\text { cara/teknik }\end{array}$ & 13 & 61,90 \\
budidaya ikan & $(21)$ & \\
2 & $\begin{array}{l}\text { Mencari informasi } \\
\text { harga }\end{array}$ & 10 & 47,62 \\
3 & $\begin{array}{l}\text { Mencari informasi } \\
\text { pengembangan }\end{array}$ & $8(21)$ & 38,10 \\
& $\begin{array}{l}\text { kelompok tani } \\
\text { Membeli }\end{array}$ & 16 & 76,19 \\
& $\begin{array}{l}\text { produk/kebutuhan } \\
\text { jaring ikan }\end{array}$ & $(21)$ & \\
Menjual Produk & 10 & 47,62 \\
& usaha jaring ikan & $(21)$ \\
\hline Sumber
\end{tabular}

Sumber : diolah dari data primer, 2015

Tabel 19, menunjukkan kegunaan responden dalam rangka usaha jaring ikan melalui internet, tertinggi adalah membeli produk/kebutuhan jaring ikan 76,19\% dan mencari informasi cara/teknik budidaya ikan $61,90 \%$. Tingginya responden memilih kegunaan setelah mengakses internet, yaitu mbeli produk/kebutuhan jaring ikan disebabkan karena kebutuhan seperti, pakan ikan, bibit ikan

\section{Kendala Dalam Pemanfaatan Internet Oleh Responden}

Kendala-kendala dalam pemanfaatan internet setelah melihat dari Tabel 13 bahkan lampiran 3 dan 4 dapat dikatakan sebagian besar responden belum sepenuhnya mempergunakan internet atau mengakses internet, karena dari 47 responden masih ada 21 orang yang belum mengakses atau $44,68 \%$. Hal ini disebabkan karena berbagai alasan. Ketidak ketersediaan alat untuk mengakses ada 11 orang responden yang menyampaikan alasan tersebut, 1 orang yang menjawab tidak ada koneksi keinternet dan 9 orang tidak memberikan alasan, (Tabel 14).

Kendala lain yang dapat disampaikan adalah walaupun ada sebagian petani responden yang sudah mampu mengakses atau mengunakan internet yaitu 26 orang atau $55,32 \%$, tetapi mereka pun masih mendapat kendala seperti akses internet yang lambat, signal yang kurang baik, kurangnya jumlah warnet, biaya internet mahal, harga komputer/perangkat lain masih mahal serta kemampuan petani dalam mengakses internet masih kurang, ini dapat dilihat pada Tabel 20. Tabel 20 menunjukan tertinggi 13 orang atau 
$27,66 \%$ responden menjawab signal yang kurang baik dan kemampuan petani dalam mengakses internet masih kurang, dan yang terendah ada $2,13 \%$ yang menjawab biaya akses internet mahal dan harga komputer/perangkat lain masih mahal. Sehingga perlu penanganan lebih baik lagi mengenai pemanfaatan internet di Desa Eris, dimana harus perlu diadakan pengenalan manfaat dan kegunaan serta caracara penggunaannya melalui penyuluhan dan pertemuan-pertemuan lainnya.

Hal lain lagi yang mungkin mempengaruhi bahkan dapat dikatakan sebagai kendala dalam pemanfaatan internet dalam rangka mencapai tujuan yaitu sudah atau belum petugas penyuluh mengunakan internet, dapat dilihat pada Tabel 21. Responden yang menjawab sudah, oleh petugas penyuluh untuk pemanfaatan internet ada 11 orang atau $23,40 \%$ sedangkan yang menjawab belum ada 36 orang atau $76,60 \%$, ini menandakan penggunaan internet bagi penyuluh belum sepenuhnya digunakan, sehingga dalam rangka pengembangan usaha jaring ikan mengalami hambatan-hambatan. Bahkan apabila dilihat dari tingkat kepuasan dari petani dalam hanya 4 orang responden saja yang menjawab sangat bermanfaat yang menjawab cukup bermanfaat 5 orang responden, 2 orang renponden menjawab sedikit bermanfaat, dan yang tidak sama sekali nihil. Untuk lebih jelasnya dapat dilihat pada 22.

Tabel 20. Pendapat Responden Mengenai Kendala Utama dalam Mengakses Internet

\begin{tabular}{clcc}
\hline No & \multicolumn{1}{c}{ Kendala Utama } & $\begin{array}{c}\text { Jumlah Responden } \\
\text { (orang) }\end{array}$ & Persentase (\%) \\
\hline 1 & Kurangnya jumlah warnet & 3 & 6,38 \\
2 & Akses internet yang lambat & 10 & 21,28 \\
3 & Signal yang kurang baik & 13 & 27,66 \\
4 & Biaya akses internet mahal & 1 & 2,13 \\
5 & Harga komputer /perangkat lain mahal & 1 & 2,13 \\
& & 13 & 27,66 \\
6 & Kemampuan petani dalam mengakses & 13 & 12,76 \\
\hline & internet masih kurang & 6 & 100 \\
\hline & Lain-lain & 47 & \\
\hline
\end{tabular}

Sumber : diolah dari data primer, 2015

Tabel 21. Pemanfaatan Internet oleh Petugas Penyuluh Pertanian Melalui Responden

\begin{tabular}{cccc}
\hline No & Pemanfaatan internet oleh penyuluh & Responden (Orang) & Persentase (\%) \\
\hline 1 & sudah & 11 & 23,40 \\
2 & belum & 36 & 76,60 \\
\hline & Jumlah & 47 & 100 \\
\hline
\end{tabular}

Sumber : diolah dari data primer, 2015

Tabel 22. Tingkat Kepuasan Petani Responden dalam Mempergunakan Internet

\begin{tabular}{clcc}
\hline No & $\begin{array}{c}\text { Tingkat kepuasan petani yang sudah } \\
\text { mempergunakan internet }\end{array}$ & Responden (Orang) & Persentase (\%) \\
\hline 1 & Tidak sama sekali & - & - \\
2 & Sedikit bermanfaat & 2 & 18,18 \\
3 & Cukup bermanfaat & 5 & 45,46 \\
4 & Sangat bermanfaat & 4 & 36,36 \\
\hline & J u m l a h & 11 & 100 \\
\hline
\end{tabular}

Sumber : diolah dari data primer, 2015 


\section{KESIMPULAN DAN SARAN}

\section{Kesimpulan}

Petani nelayan di Desa Eris yang menggunakan teknologi informasi dan komunikasi khususnya internet sebanyak 26 responden atau sebesar 55,32\%, sebagian besar petani mengakses jenis informasi melalui telepon genggam/smarphone/tablet $84,62 \%$.

Sebagian besar petan menggunakan internet 80,77 telah memanfaatkannya untuk mencari informasi tentang usaha jaring ikan.

Penggunaan yang paling dominan digunakan sebagai sarana untuk membeli produk/ kebutuhan jaring ikan, dan mencari informasi mengenai cara/teknik budidaya jaring

ikan. Kendala utama dalam pemanfaatan internet di Desa Eris yaitu masih belum baiknya koneksi internet (signal) dan masih rendahnya kemampuan petani dalam mengakses internet.

\section{Saran}

Perlu penanganan lebih baik lagi mengenai pemanfaatan internet di Desa Eris, dimana harus perlu diadakan pengenalan pemanfaat serta cara-cara penggunaannya melalui penyuluhan dan pertemuan-pertemuan lainnya sehingga teknologi informasi dan komunikasi dapat dirasakan dan diterapkan oleh petani jaring ikan di Desa Eris.

Diharapkan petani nelayan ikan terus mengembangkan usaha ini, sejalan dengan perkembangan teknologi informasi dan komunikasi, dengan menggunakan internet melalui informasi untuk komunikasi seperti mencari tentang teknik budidaya ikan yang sesungguhnya, masalah harga serta pengembangan hasil usaha jaring ikan agar dapat lebih meningkatkan pendapatan petani nelayan, sehingga lebih sejahtera.

Dalam rangka lancarnya usaha petani nelayan ikan untuk penerapan inovasi baru, baik teknologi komunikasi, produksi, teknologi sosial dan teknologi ekonomi, yang membuat bibit ikan, membuat pakan ikan hingga pemasaran atau melalukan jual beli dalam bidang agribisnis, sehingga lebih mudah memasarkan dan mengenalkan produk sampai kepelosok negeri bahkan sampai keluar negeri, perlu buatkan web site di desa Eris.

Diperlukan pula peran dari pihak pemerintah, dinas-dinas yang terkait, lembagalembaga swasta untuk dapat aktif mengadakan penyuluhan khususnya mengenai pentingnya teknologi informasi dan komunikasi untuk dapat meningkatkan usaha tani nelayan.

\section{DAFTAR PUSTAKA}

2011. Pemanenan Ikan Mujair http://www.agromaret.com/artikel/372/ pemanenan_ikan_mujair 11 Juni 2015

, 2012. Ikan Mujair/Adearisandi
$\begin{aligned} & \text { blog. } \\ & \text { Wordpress.com } \\ & \text { /2012//10/31/ikan mujair }\end{aligned}$

2014. Cara Pembenihan Budidaya Ikan Mujair. http://www.alamikan.com 11 Juni 2015

Birowo, A. T. 1986. Alih Teknologi Dalam

Bidang Agro Business. Univesitas Brawijaya Malang

Djoyohadikusumo, 1994. Berbagai Definisi Teknologi Informasi http://www.hdn.or.id/index.php/researc h/2006/

Husein,U, 1998. Sumber Daya Manusia. Jakarta, Gramedia.

Lionberger, H. F. 1960. Adoption of New Ideas and Practices The Iowa State University Press. Anes Iowa.

Martin, 2002. Pemanfaatan Teknologi Informasi dan Komunikasi Sebagai Media Pembelajaran

http://.www.slideshare.net/guest2dle29/ Gjanuari2010

Natakusumah E.K. 2002. Perkembangan Teknologi Informasi di Indonesia. Pusat Penelitian Informatika-LIPI Bandung 
Patihahuwan, Ch. 2010. Deskripsi FaktorFaktor Yang Mempengaruhi Pengembangan Kelompok Tani. Fakultas Pertanian Unsrat Manado

Prodjosuhardjo Mudjijo, 1987. Ilmu Penyuluhan Pertanian. Fakultas Pertanian Universitas Gadjah Mada Yogyakarta.

Rachmawati, I.K. 2008. Manajemen Sumber Daya Manusia. Yogyakarta.

Rosenberg, 2001. Pengaruh Teknologi Informasi di dalam Masyarakat sosial http://whaysworld.wordpress.com
Rogers, M. E. and Schoemaker, 1971. Communication of Innovation The Free Press. A. Division of Mac Millan Publishing co inc New York.

Soekartawi, 1988. Prinsip Dasar Komunikasi Pertanian Universitas Indonesia Press Jakarta.

Tjiptono M dan S.Santoso 2001. Riset Pemasaran Konsep dan Aplikasi Dengan SPSS Jakarta. PT Elex Media Komputindo

Trimo, 2006. Pengertian Kelompok Tani. Bumi Aksara. Jakarta. 